\title{
The Extent of Jordanian External Auditor Commitment in Applying ISA "240" and its Effect in Reducing Fraud in Financial Statement
}

\author{
Audeh Ahmad Bani Ahmad \\ Associate Professor \\ Accounting Department \\ Faculty of Economic and Business Administration \\ Alalbyt University \\ Jordan
}

\begin{abstract}
The purpose of this study is to determine the extent of Jordanian external auditors' commitment in the application of the ISA "240" and its effect in reducing fraud in financial statement. As such, the report focuses on application of ISA 240 provision in carrying out external auditing, the frequency of deployment of ISA 240 principles among the Jordanian external auditors and the number of financial fraud cases in Jordan that have been detected using ISA 240 tool for external auditing. The study has deployed cross-sectional survey to collect data among 21 sampled auditors in Jordan using a semi-structured questionnaire. The findings has indicated that $80.3 \%$ of the sampled auditors complies with ISA 240 regulation, 58.3\% of the sampled auditors have faced various challenges with ISA 240provisions, 52.38\% of the sampled auditors have been able to identify financial statement frauds using the ISA 240 provision, $80.3 \%$ cases of financial fraud cases identified have been reported as per ISA 240regulations and finally $70.4 \%$ of the sampled auditors have rated ISA 240 legislation as the best tool to guide auditors in identifying and reporting financial frauds .
\end{abstract}

Keywords: external auditor, fraud, IAS240.

\subsection{Introduction}

\subsection{Study Background}

External auditors have professional ways of validating the financial statements hence the ability to determine the cases of fraudulent transactions (Tum, 2015). The external auditors have the responsibilities of examining the organizations' books and records to prepare a comprehensive report that summarizes the inflow and outflow of funds hence the ability to determine the financial standing of the company. The external auditor will also identify the weaknesses of the organizations' financial system and assist with management strategies to increase the production capacity of the company (Stevenson Smith, 2012).

The substantial role of the auditors in the company's affairs has made the Jordanian legislators enact several provisions in order to articulate the rights and duties of the external auditors in business organizations (Munro \& Stewart, 2011). The Jordanian legislators have successfully carved out a special section in the Company Legislation No. 22 of 1997 to deal with 1997 and the strategic plan "Jordan 2025" to deal with matters such as content of the auditor's report, prohibitions, fraud detection and fraud control, election of the auditors and the attendance of the general assembly meetings (Lartey, 2012).

The remarkable changes in the global economic and management of the business operations in accordance to the regulatory requirements requires regional transformation to realize effective financial management. The introduction of the "Jordan 2025" legislation framework by the Jordanian government aims at raising the Jordanian competitiveness and revitalizes the economy by ensuring transparency and accountability in finance management (Ghazangs, 2014). Moreover, the "Jordan 2025"strategies also seek to facilitate the successful achievement of the goals of becoming a financial center where the investors can have confidence to investing (Black, 2010).

The Jordanian government has introduced International Standards on Auditing ISA (240) to improve the audit practices for the corporations and other financial institutions. ISA 240 presents the roles and responsibilities of the auditors in relation to fraud detection and management for financial statements (Al-Dalabih, 2018). The system also provides means of identifying and assessing the risks of the material misstatement due to fraud in corporate and financial institution management. 
The purpose of the ISA 240 in external auditing include enabling the auditors obtain sufficient appropriate audit evidence regarding the assessed risks of materials misstatement resulting from fraudulent activities through designing and implementation of the most appropriate responses(Al-Bawab, 2017). As such it helps the auditing and financial regulatory bodies to respond appropriately to the fraud during the auditing processes.

\subsection{Problem Statement}

According to ISA 240 requirements, the auditors should maintain professional skepticisms throughout the auditing process and investigate the inconsistencies in financial statements (Stevenson Smith, 2012). The document also requires that auditors design and perform procedures that are responsive to the assessed financial risks and evaluate the selection and application of the accounting policies and tools especially related to subjective measurements and complex transactions that may be indicative of fraudulent financial reporting systems (Levi, 2010).

The cases of financial mismanagement, financial frauds and poor funds control in corporate and projects are common happenings in Jordan despite the introduction of the ISA 240 system and government enacting regulatory policies to control the financial systems and auditing bodies (Tum, 2015). As such, it signifies that there is a challenge with the auditing bodies to sanitize the system in quest to achieve a transparent, credible, reliable and trustworthy financial management systems across Jordan (Kumar, 2014). The weaknesses in the public financial management system in Jordan reflects the underlying interests hence the need to strengthen the public financial management through political leadership and support with the technical skills (Chandler, 2015).

The Audit Bureau of Jordan is an independent government agency and supreme audit institution hence it would b expected to carry out its roles effectively with least political interference. The agency is responsible for auditing ministries, public departments, labour unions, co-operatives, corporations and public institutions (Al-khabash \& Al-Thuneibat, 2008). The Jordan government has most shares in the agency hence any entity of the Council of Ministers entrust the Bureau to audit its accounts. The external auditing has not been efficient enough since the introduction of the ISO 240 system of auditing in Jordan (Al-Bawab, 2017). Numerous studies have been performed to determine the effectiveness of ISO 240auditing tool however none of the studies have focused to determine the acceptance of the tool by the auditors.

\subsection{Aim of the Research}

The general objective of the research will be to determine the extent of Jordanian external auditors' commitment in the application of the ISA "240" and its effect in reducing fraud in financial statement. The specific objectives of the study include:

i. To determine the application of ISA 240 provisions while performing external auditing

ii. To determine the frequency of application of the ISA "240" among the external auditors in Jordan

iii. To determine the number of financial frauds cases detected using ISA " 240 " in Jordan by external auditors

\subsection{Significance of the Research}

The study will be of great significance to the government, the audit regulatory bodies and the corporate bodies relying on the Jordanian external auditors to identify fraudulent cases in the financial statements. The government will be able to use the study findings to determine the key areas that need strict regulatory policies to enhance the auditing and financial management in Jordanian organizations and corporate bodies. The study finding will enable the auditory agency to determine the extent at which the ISA " 240 " is deployed by the external auditors while performing the their duties hence the ability to come up with means of ensuring that all auditors in Jordan are using the tool to perform their duties in order to enhance the ability to limit the cases of financial frauds and mismanagement. The corporate bodies will also be able to enforce regulatory policies that will require the external auditors to comply with the ISA " 240 " legislations before given the contract of auditing the firm.

\subsection{Literature Review}

The effective public sector and private sector external auditing focus on achieving good governance by promoting accountability and transparency in financial management, reduction of the risks and minimizing the cases of financial frauds and corruption cases(Munro \& Stewart, 2011). In this respect, the external auditors are expected to adhere to specific rules and regulations to achieve the goals and objectives of the agency. According to the study report by Stevenson Smith (2012) the Audit Bureau of Jordan has lack tools and framework to ensure that the government legislations on better auditing practices are strictly followed to achieve the best financial management status that would attract investors in the country(Levi, 2010). According to Black (2010) the personnel selected to conduct external analysis should have a good background and skills of performing financial auditing hence he or she should be certified by the auditing standards and agencies. 
The studies by Al-Dalabih (2018) has indicated that continuous education and training on current developments in auditing practices and tools improve the performance of the auditors hence the need to ensure that auditors go for continued professional developments. Cases of undetected financial frauds have been reported in a number of organizations across Jordan according the findings from the study by Tum (2015).

It had been established that the reason behind the financial frauds are due to poor auditing tools deployed in most firms. The other reason for financial frauds in corporate bodies is the use of poor tools and policies to control the external auditing (Kumar, 2014).

The primary responsibility for the prevention and detection of fraud rests with both the government regulatory bodies and the agency managing the auditors across Jordan. According to Chandler (2015) the most important marker of good governance is transparency and reliable financial reporting since bulk of the investments are based on financial statements hence the need to establish reliability and trustworthiness in all operations. The accurate financial reporting of requires a good source of information for a myriad of stakeholders such as the government regulators, potential investors, and company mangers (Stevenson Smith, 2012). If the financial statements cannot be trusted, the investors can be scared from pumping in more finances hence deterring economic development (Munro \& Stewart, 2011).

The global corporate accounting scandals have proven that having external auditors in corporate governance is a significance move to ensure that financial frauds are managed effectively (Mishiel, \& Qasim, 2010). The competition for capital is intense in the globalized world and only states and institutions with superior corporate governance characterized with best jurisdiction will be able to attract investors and shareholders crucial for economic growth and development (Al-khabash \& Al-Thuneibat, 2008). Corporate governance entails numerous aspects of how business should be government and how the organization should interact and establish relationship with other companies, shareholders, employees, customers and the general public. Similar to state governance, the government should ensure that it establishes a healthy relationship with other governments, citizens and the international organizations for social, political and economic growth and development (Al-Bawab, 2017).

\subsection{Study Methodology}

The research methodology deployed cross-sectional study design to gather data about the use of ISA 240 provisions among the external auditors in Jordan to limit the financial frauds. The survey entailed use of Likert 5 scale questionnaires. The questionnaire entailed 14 questions and the participants were required to react by picking strongly disagree (SD), disagree (D), neither agree nor disagree (AD), agree (A) and strongly agree (SA). Jordan has about 200 certified accounting and auditing organizations hence the study was conducted across the certified accounting and auditing organizations. The study sample was determined using the Krejcie \& Morgan (1970) table that led to a sample size of 132 while maintaining confidence level of $95 \%$ and margin error of $5.0 \%$. The study sample was randomly selected from the names of accounting and auditing organizations obtained from the Jordanian Association of Certified Public Accountants and about 132 accountants, one per organization, were emailed the questionnaires to fill. All the emailed questionnaires were filled and replied for analysis. The data obtained were analyzed using statistical package for social science (SPSS) and the analysis output were tabulated to illustrate the frequencies, percentages, means and standard deviations.

\subsection{Study Findings}

Table 4.1 illustrating the frequency $(F)$ and percentages (\%) of the use of ISA 240 guidelines among the Jordanian auditors

\begin{tabular}{|c|c|c|c|c|c|c|}
\hline $\mathbf{R} / \mathbf{Q}$ & The Use of ISA 240 & 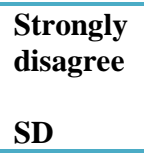 & Disagree & $\begin{array}{l}\text { Neither agree } \\
\text { nor disagree } \\
\text { AD }\end{array}$ & Agree & $\begin{array}{l}\text { Strongly } \\
\text { agree }\end{array}$ \\
\hline 1 & $\begin{array}{l}\text { I have used ISA } 240 \text { provision for external auditing } \\
\text { purpose }\end{array}$ & $26 \quad 19.7$ & 0.0 & 0.0 & 0.0 & 10680.3 \\
\hline 2 & $\begin{array}{l}\text { ISA } 240 \text { tool provides guidance during external } \\
\text { auditing }\end{array}$ & 5.3 & 3.8 & $14 \quad 10.6$ & 0.0 & 10680.3 \\
\hline 4 & $\begin{array}{l}\text { I do not know the significance of ISA } 240 \text { in } \\
\text { external auditing }\end{array}$ & 11385.6 & 5.3 & 9.1 & 0.0 & 0.0 \\
\hline 5 & $\begin{array}{l}\text { Auditing organizations in Jordan complies with ISA } \\
240\end{array}$ & 0.0 & $15 \quad 11.4$ & 6.1 & 0.0 & 10982.6 \\
\hline
\end{tabular}




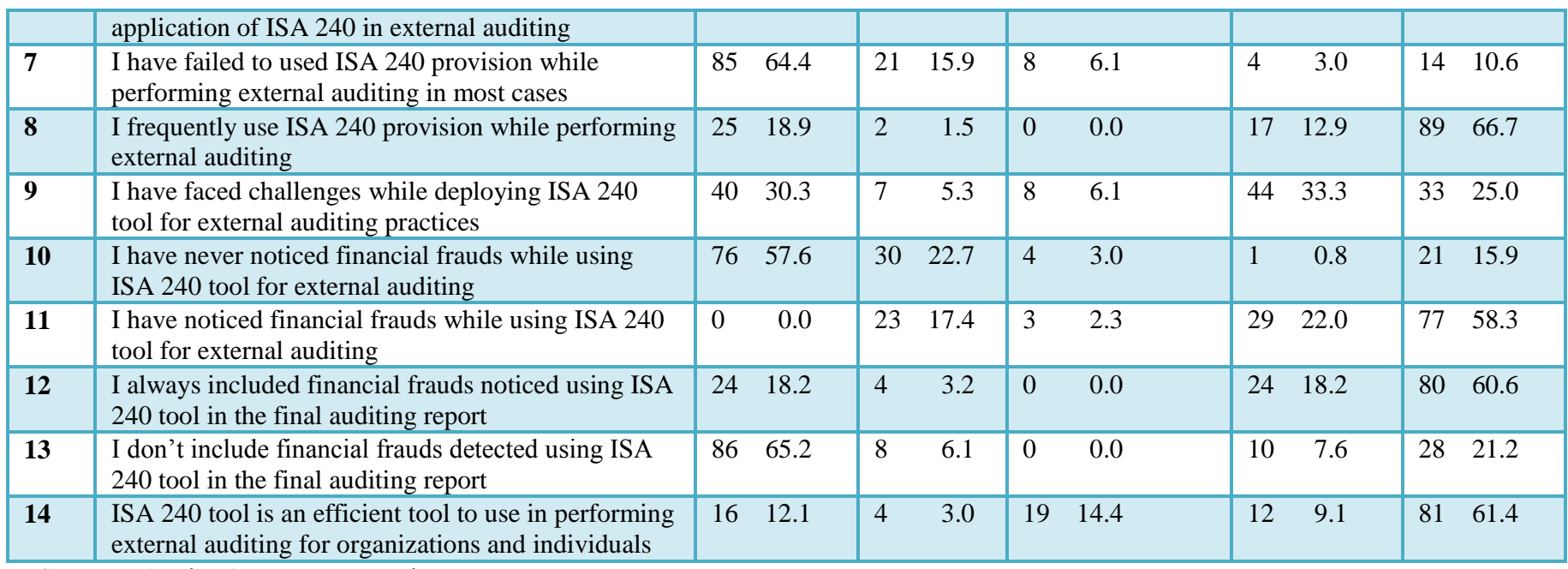

Source: Author's own research

Table 4.2 illustrating the mean, standard deviation and standard error means of various variables analyzed

\begin{tabular}{|c|c|c|c|c|}
\hline \multicolumn{2}{|r|}{ USE OF ISA 240 GUIDELINES } & \multirow{2}{*}{$\begin{array}{l}\text { Mean } \\
4.4621\end{array}$} & \multirow{2}{*}{$\begin{array}{l}\mathbf{N} \\
132\end{array}$} & \multirow{2}{*}{$\begin{array}{l}\text { Standard } \\
\text { Deviation }\end{array}$} \\
\hline 1 & I have used ISA 240 provision for external auditing purpose & & & \\
\hline 2 & ISA tool provides guidance during external auditing & 4.4621 & 132 & 1.15518 \\
\hline 3 & $\begin{array}{l}\text { I only use ISA } 240 \text { for external auditing because it is a regulatory requirement in } \\
\text { Jordan }\end{array}$ & 4.3030 & 132 & 1.17180 \\
\hline 4 & I do not know the significance of ISA 240 in external auditing & 1.2348 & 132 & 0.60355 \\
\hline 5 & Auditing organizations in Jordan complies with ISA 240 & 4.5379 & 132 & 1.02938 \\
\hline 6 & Audited organizations in Jordan insists on application of ISA 240 in external auditing & 4.2879 & 132 & 1.40626 \\
\hline 7 & $\begin{array}{l}\text { I have failed to used ISA } 240 \text { provision while performing external auditing in most } \\
\text { cases }\end{array}$ & 1.7955 & 132 & 1.32353 \\
\hline 8 & I frequently use ISA 240 provision while performing external auditing & 3.9394 & 132 & 1.60513 \\
\hline 9 & I have faced challenges while deploying ISA 240 tool for external auditing practices & 3.1742 & 132 & 1.60864 \\
\hline 10 & I have noticed financial frauds while using ISA 240 tool for external auditing & 4.2121 & 132 & 1.12589 \\
\hline 11 & I have never noticed financial frauds while using ISA 240 tool for external auditing & 1.9470 & 132 & 1.44261 \\
\hline 12 & $\begin{array}{l}\text { I always included financial frauds noticed using ISA } 240 \text { tool in the final auditing } \\
\text { report }\end{array}$ & 4.0000 & 132 & 1.54327 \\
\hline 13 & $\begin{array}{l}\text { I don't include financial frauds detected using ISA } 240 \text { tool in the final auditing } \\
\text { report }\end{array}$ & 2.1364 & 132 & 1.693151 \\
\hline 14 & $\begin{array}{l}\text { ISA } 240 \text { tool is an efficient tool to use in performing external auditing for } \\
\text { organizations and individuals }\end{array}$ & 4.0455 & 132 & 1.40807 \\
\hline
\end{tabular}

Source: Author's own research 
Table 4.3 illustrating the one sample statistics

\begin{tabular}{|c|c|c|c|c|c|c|c|}
\hline \multirow[b]{3}{*}{$\mathbf{R} / \mathbf{Q}$} & \multirow[b]{3}{*}{ Use of ISA 240 guidelines } & \multicolumn{6}{|c|}{ Test Value $=0$} \\
\hline & & \multirow[b]{2}{*}{$\mathrm{t}$} & \multirow[b]{2}{*}{$\mathrm{df}$} & \multirow[b]{2}{*}{ Sig. (2-tailed) } & \multirow{2}{*}{$\begin{array}{l}\text { Mean } \\
\text { Differe } \\
\text { nce }\end{array}$} & \multicolumn{2}{|c|}{$\begin{array}{l}\text { 95\% Confidence } \\
\text { Interval of the } \\
\text { Difference }\end{array}$} \\
\hline & & & & & & Lower & Upper \\
\hline 1 & $\begin{array}{l}\text { I have used ISA } 240 \text { provision for external auditing } \\
\text { purpose }\end{array}$ & 30.305 & 132 & 0.000 & 4.262 & 3.937 & 4.487 \\
\hline 2 & $\begin{array}{l}\text { ISA240 tool provides guidance during external } \\
\text { auditing }\end{array}$ & 44.379 & 132 & 0.000 & 4.462 & 4.263 & 4.661 \\
\hline 3 & $\begin{array}{l}\text { I only use ISA } 240 \text { for external auditing because it is a } \\
\text { regulatory requirement in Jordan }\end{array}$ & 42.190 & 132 & 0.000 & 4.303 & 4.101 & 4.505 \\
\hline 4 & $\begin{array}{l}\text { I do not know the significance of ISA } 240 \text { in external } \\
\text { auditing }\end{array}$ & 23.506 & 132 & 0.000 & 1.235 & 1.131 & 1.339 \\
\hline 5 & $\begin{array}{l}\text { Auditing organizations in Jordan complies with ISA } \\
240\end{array}$ & 50.648 & 132 & 0.000 & 4.538 & 4.361 & 4.715 \\
\hline 6 & $\begin{array}{l}\text { Audited organizations in Jordan insists on application } \\
\text { of ISA } 240 \text { in external auditing }\end{array}$ & 34.120 & 132 & 0.000 & 4.288 & 4.011 & 4.504 \\
\hline 7 & $\begin{array}{l}\text { I have failed to used ISA } 240 \text { provision while } \\
\text { performing external auditing in most cases }\end{array}$ & 15.586 & 132 & 0.000 & 1.796 & 1.568 & 2.023 \\
\hline 8 & $\begin{array}{l}\text { I frequently use ISA } 240 \text { provision while performing } \\
\text { external auditing }\end{array}$ & 28.741 & 132 & 0.000 & 3.939 & 3.696 & 4.243 \\
\hline 9 & $\begin{array}{l}\text { I have faced challenges while deploying ISA } 240 \text { tool } \\
\text { for external auditing practices }\end{array}$ & 22.044 & 132 & 0.000 & 3.174 & 3.096 & 3.707 \\
\hline 10 & $\begin{array}{l}\text { I have never noticed financial frauds while using ISA } \\
240 \text { tool for external auditing }\end{array}$ & 15.506 & 132 & 0.000 & 1.947 & 1.699 & 2.195 \\
\hline 11 & $\begin{array}{l}\text { I have noticed financial frauds while using ISA } 240 \\
\text { tool for external auditing }\end{array}$ & 42.982 & 132 & 0.000 & 4.212 & 4.018 & 4.406 \\
\hline 12 & $\begin{array}{l}\text { I always include financial frauds noticed using ISA } \\
240 \text { tool in the final auditing report }\end{array}$ & 27.094 & 132 & 0.000 & 4.000 & 3.504 & 4.056 \\
\hline 13 & $\begin{array}{l}\text { I don't include financial frauds detected using ISA } \\
240 \text { tool in the final auditing report }\end{array}$ & 14.497 & 132 & 0.000 & 2.136 & 1.845 & 2.428 \\
\hline 14 & $\begin{array}{l}\text { ISA } 240 \text { tool is an efficient tool to use in performing } \\
\text { external auditing for organizations and individuals }\end{array}$ & 33.009 & 132 & 0.000 & 4.046 & 3.805 & 4.288 \\
\hline
\end{tabular}

Source: Author's own research

\subsection{Findings Analysis}

The SPSS analysis has indicated that $80.3 \%$ (106 of the respondents) of the sampled population (132 participants) strongly agree to have used ISA 240 provision for external auditing as indicated in table 4.1. The table 4.1 also indicates that $66.7 \%$ of the sampled population frequently uses ISA 240 regulatory requirements while performing external auditing in Jordan. 80.4\% (96 participants) of the sampled population used ISA 240 tool because it is a regulatory requirement in Jordan as indicated in table 4.1.

Moreover, 80.3\% (106 participants) of the sampled population strongly agreed to have been using the ISA 240 system to provide guidance during external auditing practices in Jordan as indicated in table 4.1. Table 4.1 further reveals that most auditors in Jordan understand the significance of ISA 240 when it comes to external auditing practices. Only $9.1 \%$ (12 participants) of the sampled population do not understand the significance of ISA 240 provision in external auditing. 
Majority of auditing organizations in Jordan (82.6\%) complies with ISA 240 regulatory requirements while $80.3 \%$ of the audited organizations insist on application of ISA 240 regulatory policies while performing external auditing according to table $4.1 .80 .3 \%$ of the study participants (106 people) have agreed to have noticed financial frauds while using ISA 240 tool to perform external auditing and $78.8 \%$ of the auditors have included the financial fraudulence cases identified via ISA 240 in their final reports as indicated in table 4.9 and table 4.1.Various auditors have faced challenges with ISA 240 provisions as indicated in table 4.1. 58.3\% (77 participants) of the sampled population have agreed to have experienced some difficulties while trying to comply with the regulatory requirement. However, $70.4 \%$ (93 participants)have reported that ISA 240 tool is an efficient provision deployable for external auditing to identify and reduces the cases of financial frauds in organizations based in Jordan.

The mean for respondents that use ISA 240 guidelines in Jordan is 4.4621 which indicates that majority of respondents have agreed to be utilized the ISA 240 protocol in their operations (table 4.2).Most respondents have agreed (mean of 4.000) that they do include the financial challenges identified using ISA 240 guidelines in their report hence a proof that the Jordanian auditors are committed in applying the ISA 240 guidelines in their practices. The p-value for all the analyzed variables has been found to be 0.000 hence an indication that the explored variables are positively significant (Table 4.3).

\subsection{Discussion}

Improving the governance is a significance practice to facilitate the Jordan's plans of improving the modern economy. The modern economy can only be achieved by ensuring transparency in financial management in corporate bodies and the government departments (Jordan Economic Monitor, 2014). In order to ensure accountability and transparency in financial management, the government of Jordan and the Jordanian association of the certified public accountants (JACPA) have jointly agreed to deploy ISA 240 policies in auditing practices as a way of minimizing the possible frauds reported in financial statements during external auditing across Jordan(Al-Dalabih, 2018).

According to ISA 240 legislation, a financial fraud risks is defined as events or conditions that indicate likelihood or incentive to commit a financial fraud or provides an ample opportunity to commit financial fraud. The report findings are in agreement with Black (2010) findings that financial frauds are common across Jordan corporate bodies, government agencies and the business organizations. $80.3 \%$ of the auditors sampled have reported that they have encountered financial frauds during external auditing practices. The percentage of the sampled auditors that have reported financial statement frauds during external auditing is almost equal to the number of the auditors complying with ISA 240 legislatives (78.8\%) hence an indication that the use of ISA 240 tool can help to identify the fraud cases (Gazdar, \& Cherif, 2014). Moreover, the number of fraud cases identified and reported as a result of compliance with the ISA 240 legislation is an enough proof that the Jordan auditors are committed to apply ISA 240 in external auditing practices(Ghazangs, 2014).

The auditors have been complying with the ISA 240 auditing practices by pointing the cases in their final reports hence making it easy for the authorities to confront the individuals pointed out in the report to be responsible for the financial crisis reported. The auditor profession in Jordan has undergone dramatic transformation since its inception in 1944(Lartey, 2012). The profession is currently tightly regulated by the regulatory bodies such as JACPA and the audit bureau of Jordan agency to ensure that international standards are followed by the professionals to raise the quality of services offered by the auditors across Jordan. As such, ISA 240 tool is a common denominator that unites all the auditors to ensure that all clients in need of auditing services are accorded the right services (Munro \& Stewart, 2011).

However, there is a smaller group of auditors (19.7\%) that do not make use of ISA 240 legislatives while performing auditing in Jordanian organizations. The possible reason for not using the ISA 240 tool among this category of auditors may be due to background knowledge of the ISA 240 tool and its significance in reducing the financial statement frauds (Cunningham, 2004). However, 70.5\% of the sampled auditors across Jordan have rated the ISA 240 tool as the best tool to minimize the fraudulent cases in financial statements hence deeply rooted to ensure that financial frauds are completely dealt with accordingly in Jordan (Tum, 2015).

According to the study findings, $80.3 \%$ of the auditors reported that the corporate bodies and business organizations across Jordan recommends that the hired internal and external auditors must comply with the ISA 240 regulations in order to audit their financial records (Levi, 2010).

This shows that the corporate bodies and the business organizations are also supporting the deployment of the ISA 240 regulations to sanitize the financial management systems across Jordan to have transparent and trustworthy financial systems that would attract investors and shareholders to develop the economy of Jordan to reach the modern economy levels (Stevenson Smith, 2012).

\subsection{Recommendations and Future Studies}


The number of auditors and auditing organizations that do not comply with ISA 240 regulation is still significant in Jordan as indicated by the standard deviation of 1.15518 and 1.02938 respectively. The key reasons for not complying with ISA 240 requirement are due to negligence depicted by the fact that some auditors do not see any significance of the regulatory policy. As such there is a need to come up with a way of enlightening all the auditors and auditing organizations across Jordan to always adhere to ISA 240 provisions. It is therefore recommended that all the auditors practicing in Jordan should be accessed annually to determine their familiarity with the policies and requirements outlined in ISA 240 document. This will help to ensure compliance among the audit practitioners across Jordan. Only auditors with enough knowledge and understanding of ISA 240 regulatory requirements should be licensed.

The future studies should focus on determining the challenges faced by the auditors in Jordan while complying with the ISA 240 provisions. The future studies should also focus on identifying the areas in ISA 240 legislations that require amendments in order to have the most effective means of managing and regulating the external auditing practices across Jordan.

\subsection{Conclusion}

The study findings indicate that Jordan external auditors are committed to complying ISA 240 legislation in their practices. Most of the sampled auditors have agreed to deploy ISA 240 principles in their practices, the business organizations and corporate bodies have also been reported to hire only auditors complying with ISA 240 requirements. The bodies in charge of regulating the auditing profession such as JACPA and Audit Bureau of Jordan fully support the ISA 240 legislations hence an indication that the external auditors across Jordan are compliant to ISA 240 principles. The ISA 240 is effective in identifying the financial statement frauds. This has been shown by the fact that external auditors deploying ISA 240 principles have been able to identify and report instances of financial statement frauds.

\section{References}

Al-Bawab, A. A. (2017). The Extent to Which Jordanian External Auditor Comply with the Planning Process for Auditing the Private Jordanian Universities. Journal of Business Management \& Economics, 05(09), 01-06. doi:10.15520/jbme.2017.vol5.iss9.265.pp01-06

Al-Dalabih, A. N. (2018). The Role of External Auditor in Protecting the Financial Information Listed in the Financial Statements in the Jordanian Industrial Companies. Journal of Modern Accounting and Auditing, 14(1), 1-16. doi:10.17265/1548-6583/2018.01.002

Al-khabash, A. A., \& Al-Thuneibat, A. A. (2008). Earnings management practices from the perspective of external and internal auditors. Managerial Auditing Journal, 24(1), 58-80. doi:10.1108/02686900910919901

Black, W. K. (2010). Control Frauds as Financial Super-Predators: How 'Pathogens' Make Financial Markets Inefficient. Journal of Accounting, 18(3), 78-92. doi:10.2139/ssrn.1590400

Chandler, R. (2015). The Auditing Practices Board and Auditing Standards in Jordan. Current Issues in Auditing Current issues in auditing, 12(4), 165-180. doi:10.4135/9781446219133.n9

Cunningham, L. A. (2004). Facilitating auditing's new early warning system: Control disclosure, auditor liability, and safe harbors. Hastings Law Journal, 55 (9), 1449-1469.

Gazdar, K., \& Cherif, M. (2014). The quality of institutions and financial development in countries: An empirical investigation. Risk governance \& control: financial markets \&institutions, 4(4), 65-80. http://doi.org/10.22495/rgcv4 i4c1art1

Ghazangs, K. (2014). Cultural Changes in External Auditing. Effective Auditing for Corporates : Key Developments in Practice and Procedures, 15(1), 1-56. doi:10.5040/9781472920447.0006

Jordan Economic Monitor. (2014). Maintaining stability and fostering shared prosperity amid regional turmoil. Retrieved from July 14, 2017 from the World Wide Web: www.worldbank.org.jo.

Krejcie, R. V., \& Morgan, D. W. (1970). Determining sample size for research activities. Educational and Psychological Measurement, $30(3), 607-610$.

Kumar, B. (2014). Frauds against the Revenue. Journal of Financial Crime, 7(2), 175-178. doi:10.1108/eb025936

Lartey, R. (2012). Are Public Company Auditors Complicit in Financial Statement Frauds? Jordanian Journal of Accounting, 13(5), 87106. doi:10.2139/ssrn.2029118

Levi, M. (2010). Hitting the suite spot: sentencing frauds. Journal of Financial Crime, 17(1), 116-132. doi:10.1108/13590791011009400

Mishiel, S., \& Qasim, A. (2010). External Auditors' Reliance on Internal Auditors and its Impact on Audit Fees: An Empirical Investigation. Managerial Auditing Journal, 25(6), 509-525.

Munro, L., \& Stewart, J. (2011). External auditors' reliance on internal auditing: further evidence. Managerial Auditing Journal, 26(6), 464-481. doi:10.1108/02686901111142530

Stevenson Smith, G. (2012). Can an auditor ever be a first responder to financial frauds? Journal of Financial Crime, 19(3), $291-304$. doi:10.1108/13590791211243138

Tum, K. (2015). Investigating Frauds in Government Accounting. Asian Economic and Financial Review, 5(6), 892-907. doi:10.18488/journal.aefr/2015.5.6/102.6.892.907 